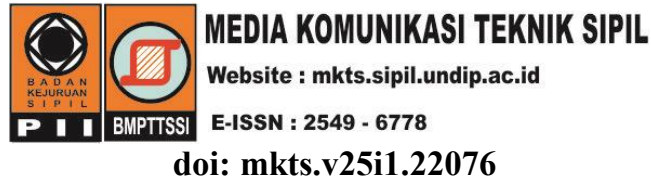

\title{
Kajian Penentuan Tarif Bus Trans Koetaradja berdasarkan Ability to Pay (ATP) dan Willingness to Pay (WTP)
}

\author{
"Renni Anggraini', Sugiarto ${ }^{1}$, Irin Caisarina ${ }^{2}$, Muhammad Ahlan' ${ }^{1}$, Dhuyufur Rahmani ${ }^{3}$, \\ Erlinawati Jalil ${ }^{3}$ \\ ${ }^{1}$ Fakultas Teknik, Jurusan Teknik Sipil, Universitas Syiah Kuala, Banda Aceh, \\ ${ }^{2}$ Fakultas Teknik, Jurusan Arsitektur dan Perencanaan, Universitas Syiah Kuala, Banda Aceh, \\ ${ }^{3}$ Fakultas Teknik, Mahasiswa Prodi Magister Teknik Sipil, Universitas Syiah Kuala, Banda Aceh, \\ *) renni.anggraini@unsyiah.ac.id
}

Received: 14 Februari 2019 Revised: 27 Mei 2019 Accepted: 31 Mei 2019

\begin{abstract}
Trans Koetaradja bus is managed by the government of Aceh Province to improve the urban public transport system. In order to appeal people to use this bus, the local government provides subsidy and applies the free fare, until today. It is expected that, when the subsidy is revoked in a few years ahead, people will get accustomed to use this bus. This research was conducted to observe public perceptions on the desired fare through ability to pay (ATP) and willingness to pay (WTP) analysis. Primary data was collected by doing survey over distributing questionnaires to the citizen. The bus corridors observed were on corridors I, III, and $I V$. The results showed that, the ATP-WTP of students were above the operator's proposed tariff for all corridors. However, to attract those students to use the bus, it is recommended that the operator's proposed tariff (IDR 2,000 for each corridor) should be applied. For the general public category (PNS/TNI/Polri, Private Employees, Housewives, and other communities), the proposed tariff for each corridors were in between the average value of ATP-WTP. In that sense, tariff determination can be applied based on the average WTP value. However, the operator's proposed tariff for the public is still also feasible, subject to improving the level of services.
\end{abstract}

Keywords: Trans Koetaradja bus, bus fare, ATP, WTP, Banda Aceh.

\begin{abstract}
Abstrak
Bus Trans Koetaradja dikelola oleh pemerintah daerah Provinsi Aceh untuk memperbaiki sistem angkutan umum perkotaan. Untuk menarik minat masyarakat dalam menggunakan bus tersebut, pemerintah daerah memberikan subsidi dan menggratiskan bus tersebut bagi masyarakat. Setelah subsidi nantinya dicabut, diharapkan masyarakat sudah terbiasa menggunakan bus ini. Penelitian ini dilakukan untuk mengetahui minat masyarakat dalam menggunakan bus saat ini dan mengetahui persepsi masyarakat mengenai tarif yang diinginkan dengan menggunakan analisis terhadap ability to pay (ATP) dan willingness to pay (WTP). Pengambilan data primer dilakukan dengan survei penyebaran kuesioner terhadap masyarakat. Koridor bus yang ditinjau adalah pada koridor I, III, dan IV. Berdasarkan hasil yang diperoleh, nilai ATP-WTP mahasiswa/pelajar berada di atas tarif usulan pengelola untuk ketiga koridor. Namun demikian, untuk menarik minat mahasiswa/pelajar, sebaiknya tarif usulan pengelola ( $R p$ 2.000,00 untuk setiap koridor) dapat diterapkan. Untuk kategori masyarakat umum (PNS/TNI/Polri, Pegawai Swasta, Ibu Rumah Tangga, dan masyarakat lainnya), tarif usulan pengelola berada di antara nilai ATP-WTP rata-rata. Dalam hal ini, penetapan tarif dapat dilakukan berdasarkan nilai WTP rata-rata. Akan tetapi, tarif usulan pengelola untuk masyarakat umum juga masih layak diterapkan, dengan syarat dilakukan perbaikan tingkat pelayanan.
\end{abstract}

Kata kunci: Bus trans Koetaradja, tarif bus, ATP, WTP, Banda Aceh. 


\section{Pendahuluan}

Seperti halnya pergerakan masyarakat perkotaan di Indonesia, pergerakan masyarakat di Provinsi Aceh juga lebih banyak didominasi oleh pergerakan dengan menggunakan kendaraan pribadi. Pertumbuhan mobil dan sepeda motor sekitar $10 \%$ dan $15 \%$ per tahun, sedangkan panjang jalan hanya bertambah kurang dari $1 \%$ per tahun (Susantono, et al., 2011). Sepeda motor merupakan kendaraan pribadi yang paling banyak digunakan oleh masyarakat, baik untuk kegiatan bekerja maupun untuk kegiatan selain bekerja (Anggraini, et al., 2017). Untuk menekan penggunaan kendaraan pribadi dan mengurangi terjadinya kemacetan lalulintas, maka penggunaan angkutan umum di perkotaan perlu ditingkatkan.

Bus Trans Koetaradja merupakan salah satu angkutan umum perkotaan yang dikelola oleh Pemerintah Daerah Provinsi Aceh, melalui Dinas Perhubungan Provinsi Aceh, untuk melayani pergerakan penduduk di Kota Banda Aceh dan sebagian penduduk di Kabupaten Aceh Besar. Sejak beroperasinya di awal Mei 2016 sampai dengan awal tahun 2019, Dinas Perhubungan Provinsi Aceh masih belum menetapkan tarif resminya. Untuk menarik minat masyarakat menggunakan bus Trans Koetaradja ini, pemerintah daerah Provinsi Aceh masih memberikan subsidi terhadap operasional bus-bus tersebut. Saat ini digunakan sistem $e$ ticketing brizzi yang berfungsi sebagai alat untuk pendataan jumlah penumpang bus Trans Koetaradja dengan tarif sebesar Rp1,00 untuk kategori pelajar dan Rp2,00 untuk kategori mahasiswa dan masyarakat umum. Namun demikian, antusiasme masyarakat juga masih rendah.

Sebelum bus Trans Koetaradja dioperasikan, minat masyarakat untuk beralih ke bus ini juga sangat rendah, hanya sekitar $38 \%$ responden yang mau berpindah dari moda pribadi ke bus Trans Koetaradja (Rahmi, 2016). Pengelola bus Trans Koetaradja telah menghitung besaran tarif bus berdasarkan biaya operasional (BOK) bus. Namun demikian, menurut Nuworsoo et al (2008), penentuan tarif angkutan umum sebaiknya juga mempertimbangkan biaya perjalanan dan kemampuan pengguna angkutan. Penentuan besarnya tarif sebaiknya dengan cara mempertimbangkan karakteristik masyarakat.

Menurut McCollon \& Pratt (2004), masyarakat pada kota yang ukurannya lebih besar cenderung untuk lebih setuju pada perubahan tarif angkutan umum. Salah satu metode penentuan tarif dengan mempertimbangkan biaya perjalanan, kemampuan pengguna angkutan, dan kemauan pengguna angkutan untuk membayar adalah konsep tarif berdasarkan ability to pay (ATP) dan willingness to pay (WTP).

Penelitian ini bertujuan untuk mengetahui persepsi masyarakat mengenai tarif bus Trans Koetaradja yang sesuai dengan kemampuan dan kemauan masyarakat (ATP dan WTP). Besaran tarif yang telah ditetapkan oleh pengelola bus Trans Koetaradja akan dibandingkan dengan kemampuan dan kemauan masyarakat yang diteliti pada penelitian ini. Artikel ini terdiri dari beberapa bagian. Pada bab selanjutnya akan dijelaskan mengenai metode penelitian, yaitu lokasi penelitian, cara penentuan dan pengambilan sampel, teori mengenai ATP-WTP, dan penelitian-penelitian yang terkait dengan ATP-WTP. Pada bab berikutnya akan dijelaskan mengenai hasil dan pembahasan. Setelah itu akan ditutup dengan simpulan dan saran.

\section{Metode}

\section{Lokasi dan waktu penelitian}

Penelitian ini dilakukan di Kota Banda Aceh dan sebagian Kabupaten Aceh Besar, di beberapa koridor yang ditetapkan, yaitu Koridor I, III, dan IV. Koridor I berada di Kota Banda Aceh, Koridor III dan IV berada di Kota Banda Aceh dan sebagian Kabupaten Aceh Besar. Untuk lebih jelasnya dapat dilihat pada Gambar 1.

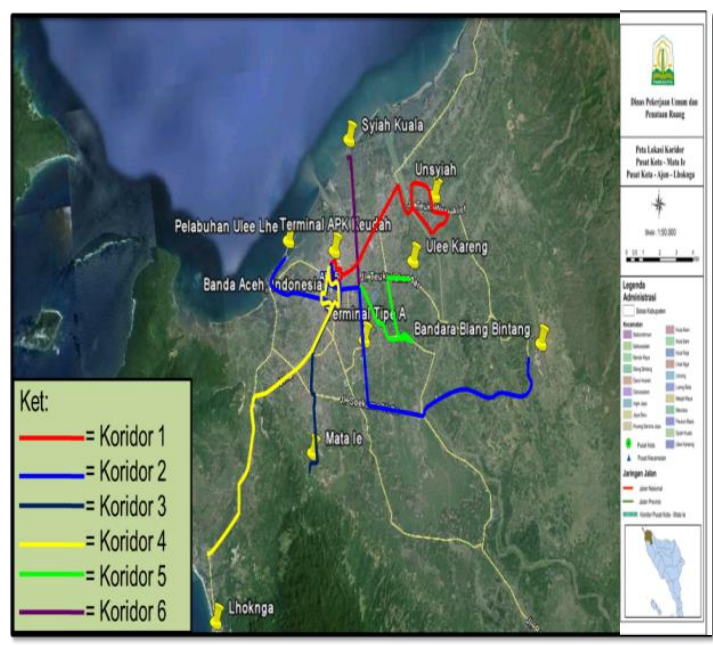

Gambar 1. Peta koridor bus trans Koetaradja yang melayani penduduk di Kota Banda Aceh dan Kab. Aceh Besar

Pengambilan data dilakukan pada tahun 2017-2018 dengan melakukan penyebaran kuesioner. Pada saat penelitian ini dilakukan, bus pada koridor I telah beroperasi, sedangkan bus pada koridor III dan IV belum beroperasi. Hal ini mempengaruhi cara penyebaran kuisioner. Penyebaran kuesioner untuk koridor I dilakukan pada beberapa tempat yang 
berbeda. Kuesioner untuk pelajar disebarkan di sekitar halte yang berdekatan dengan sekolah, kuesioner untuk mahasiswa disebarkan di lingkungan universitas yang berada di sepanjang koridor I yaitu UIN Ar-Raniry dan Universitas Syiah Kuala (UNSYIAH). Kuesioner untuk masyarakat umum dan manula/disabilitas disebarkan di dalam Bus Trans Koetaradja yang sedang beroperasi. Untuk koridor III dan IV, penyebaran kuesioner dilakukan ke rumah-rumah (home interview survey) terhadap responden masyarakat umum dan mahasiswa/pelajar yang berada di sekitar koridor. Kuesioner berisikan pertanyaan-pertanyaan mengenai karakteristik responden seperti umur, jenis kelamin, jenis pekerjaan, rata-rata pendapatan per bulan, biaya pengeluaran transportasi per bulan, dan lain-lain. Selain itu juga kuesioner berisikan pertanyaan mengenai karakteristik pergerakan seperti tujuan perjalanan, jumlah pergerakan per hari, frekuensi menggunakan bus Trans Koetaradja, dan lain-lain.

Jumlah responden ditentukan berdasarkan rumus Slovin. Metode pengambilan sampel adalah stratified random sampling, yaitu memperhatikan strata (tingkatan) dengan cara acak. Jumlah sampel pada penelitian ini adalah sebesar 200 sampel untuk Koridor I dan masing-masing 110 sampel untuk Koridor III dan IV. Toleransi kesalahan ditentukan sebesar $10 \%$.

\section{Teknik analisis}

Teknik analisis yang digunakan dalam penelitian ini adalah metode household budget dan stated preference (Julien dan Mahalli, 2014). Metode household budget digunakan untuk mengukur tingkat kemampuan masyarakat dalam membayar tarif bus, untuk mengestimasi ATP. Sedangkan metode stated preference digunakan untuk mengetahui tingkat kemauan masyarakat dalam membayar bus Trans Koetaradja, yang digunakan untuk mengukur nilai WTP.

\section{Ability to Pay (ATP) dan Willingness to Pay (WTP)}

Ability to pay atau kemampuan untuk membayar adalah kemampuan seseorang untuk membayar jasa pelayanan yang diterimanya berdasarkan penghasilan yang dianggap ideal (Rumiati et al, 2013). Willingness to pay atau kemauan untuk membayar adalah kesediaan pengguna untuk mengeluarkan imbalan (dalam bentuk uang) atas jasa yang diperolehnya (Julien \& Mahalli, 2014).

Menurut Tamin, et al (1999), dalam penentuan tarif angkutan sering terjadi ketidaksesuaian antara ATP dan WTP. Ada beberapa kondisi yang mungkin terjadi antara lain, (1) ATP $>$ WP $\rightarrow$ Kondisi ini menunjukkan kemampuan membayar seseorang lebih besar dari keinginannya membayar jasa transportasi. Hal ini terjadi ketika penghasilan pengguna relatif tinggi sedangkan pelayanan jasa tersebut rendah (disebut dengan choice riders); (2) $\mathrm{ATP}=$ WTP $\rightarrow$ Kondisi ini menunjukkan kemampuan dan kemauan membayar jasa yang digunakan adalah sama. Pada kondisi ini terjadi keseimbangan antara utilitas pengguna dengan biaya yang dikeluarkan; (3) ATP $<$ WTP $\rightarrow$ Kondisi ini menunjukkan keinginan pengguna untuk membayar jasa lebih besar dari kemampuan yang dimiliki (disebut dengan captive riders).

Menurut Permata (2012), apabila parameter ATP dan WTP yang ditinjau, maka aspek pengguna dijadikan subyek yang menentukan nilai tarif, berdasarkan prinsip-prinsip yang pertama ATP merupakan fungsi dari kemampuan membayar, sehingga nilai tarif yang diberlakukan sedapat mungkin tidak melebihi nilai ATP kelompok masyarakat sasaran. Untuk itu diperlukan campur tangan pemerintah dalam bentuk subsidi, pada kondisi nilai Tarif > ATP. Kedua WTP merupakan fungsi dari tingkat kepuasan terhadap pelayanan angkutan umum, sehingga bila nilai WTP masih berada dibawah ATP maka masih dimungkinkan melakukan peningkatan nilai tarif dengan perbaikan kinerja pelayanan. Dan yang terakhir apabila perhitungan tarif berada jauh dibawah ATP dan WTP, maka terdapat keleluasaan dalam perhitungan nilai tarif baru.

Penelitian mengenai penetapan tarif angkutan umum di Indonesia berdasarkan ATP dan WTP telah banyak dilakukan. Safitri (2016) melakukan penelitian pada angkutan kota (angkot) di Kota Pangkalpinang. Pendekatan yang digunakan dalam analisis ATP adalah berdasarkan besarnya alokasi biaya transportasi terhadap pendapatan dan frekuensi perjalanan dalam 1 bulan. Untuk analisis WTP dilakukan berdasarkan kemauan membayar masyarakat berdasarkan pelayanan angkot saat itu.

Hasil yang diperoleh menunjukkan bahwa, kemampuan membayar masyarakat, yang terdiri dari beberapa kategori (bekerja, tidak bekerja, dan pelajar/mahasiswa), jauh di atas tarif yang berlaku. Namun demikian, WTP nya berada di bawah tarif yang berlaku.

Joewono (2009) melakukan penelitian mengenai kemauan dan kemampuan membayar pengguna paratransit di Kota Bandung, dengan menggunakan metode ordinal probit dan regresi logistic binomial. Hasil analisis menunjukkan bahwa masyarakat memiliki persepsi yang berbeda dalam penilaian ATP-WTP. Selain itu, analisis juga menjelaskan 
mengenai kelompok pengguna yang memiliki kecenderungan untuk menetapkan nilai yang lebih tinggi dari tarif yang ditetapkan. Penelitian lainnya dilakukan oleh Aviasti \& Djamaludin (2014), serta Wulansari, et al (2015).

Julien dan Mahalli (2014) menyatakan, dengan menggunakan metode household budget, dapat dicari besaran ATP. Persamaan untuk menghitung ATP adalah sebagai berikut:

$\mathrm{ATP}=\frac{\mathbf{I}_{\mathrm{x}} \cdot \mathbf{P}_{\mathrm{p}} \cdot \mathbf{P}_{\mathrm{t}}}{\mathrm{T}_{\mathrm{r}}}$

Dimana ATP merupakan daya beli responden $(\mathrm{Rp} / \mathrm{km}), \quad \mathrm{I}_{\mathrm{x}}$ merupakan Tingkat penghasilan responden per bulan (Rp/bulan), $\mathrm{P}_{\mathrm{p}}$ merupakan: persentase budget untuk transportasi per bulan dari total penghasilan, $\mathrm{P}_{\mathrm{t}}$ merupakan persentase alokasi biaya transport yang digunakan untuk angkutan kota, dan $\mathrm{T}_{\mathrm{r}}$ merupakan total panjang perjalanan responden per bulan ( $\mathrm{Km} / \mathrm{bulan})$.

Pada penelitian ini, nilai ATP merupakan kemampuan responden untuk membayar tarif angkutan umum (Rp/penumpang). Sedangkan $\mathrm{Tr}$ merupakan frekuensi responden dalam menggunakan bus dalam sebulan. Selanjutnya akan dilakukan pengkategorian ATP berdasarkan jenis pekerjaan, sebagai berikut:

$\mathrm{ATP}_{\mathrm{JP}}=\frac{\sum(\text { ATP per jenis pekerjaan })}{\text { jumlah responden per jenis pekerjaan }}$

Menurut Setijowarno \& Putranto (2015), Willingness To Pay (WTP) adalah kesediaan pengguna untuk mengeluarkan imbalan atas jasa yang diperolehnya. Pendekatan yang digunakan dalam analisis WTP didasarkan pada persepsi pengguna terhadap tarif dari jasa pelayanan angkutan umum tersebut. WTP dalam permasalahan transportasi dipengaruhi oleh beberapa faktor, antara lain (1) produksi jasa angkutan yang disediakan oleh pengusaha; (2) kualitas dan kuantitas pelayanan yang diberikan pengusaha; (3) utilitas pengguna terhadap angkutan umum tersebut; (4) penghasilan pengguna.

Kemauan membayar juga didasarkan pada konsep surplus konsumen (customer surplus), yaitu selisih antara kesediaan membayar yang merupakan nilai utilitas yang diperoleh dari barang atau jasa yang dibeli dengan harga sebenarnya dibayarkan. Sehingga sering ditemukan sekelompok pengguna jasa transortasi yang bersedia untuk membayar lebih dari tarif yang telah ditentukan.

Menurut Tamin, et al (1999), faktor-faktor yang mempengaruhi WTP antara lain: (1) persepsi pengguna terhadap tingkat kualitas pelayanan; (2) utilitas pengguna terhadap angkutan umum yang digunakan; (3) fasilitas yang disediakan oleh operator; (4) pendapatan pengguna. Perhitungan nilai WTP dalam penelitian ini dilakukan dengan menggunakan stated preference. Nilai WTP akan dihitung berdasarkan tiap opsi yang ditawarkan dalam kuesioner dikalikan dengan jumlah responden tiap opsi. Perkalian tersebut kemudian akan dibagi dengan total jumlah responden, seperti terlihat pada Persamaan 3:

$\mathrm{WTP}=\frac{\sum \text { (tarif tiap opsi } \mathrm{x} \text { jumlah responden tiap opsi) }}{\text { jumlah responden }}$

Nilai WTP untuk masing-masing jenis pekerjaan dapat dilihat pada Persamaan 4.

$\mathrm{WTP}_{\mathrm{JP}}=\frac{\sum(\mathrm{WTP} \text { per jenis pekerjaan })}{\text { jumlah responden per jenis pekerjaan }}$

Dimana WTP $=$ WTP rata-rata untuk setiap opsi tarif yang ditetapkan di kuesioner, $\mathrm{WTP}_{\mathrm{JP}}=\mathrm{WTP}$ untuk setiap jenis pekerjaan.

Gambar 2 menyajikan strategi penentuan tarif berdasarkan ATP dan WTP. Jika tarif yang ditentukan lebih rendah dari ATP dan WTP, maka tidak dibutuhkan perbaikan kinerja pelayanan. Jika tarif yang ditentukan lebih rendah dari ATP dan lebih besar dari WTP, maka dibutuhkan perbaikan kinerja pelayanan. Jika tarif yang ditentukan lebih besar dari ATP, maka dibutuhkan subsidi. Pengelola Bus Trans Koetaradja telah menetapkan tarif bus, yang disajikan pada Tabel 1. Tarif tersebut berdasarkan perhitungan biaya operasional bus.

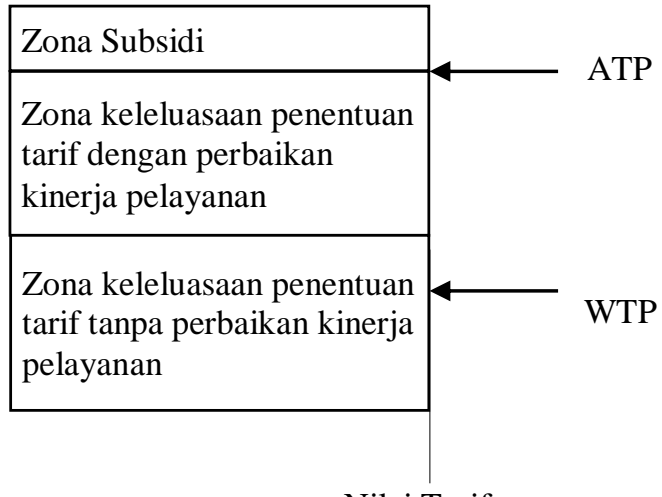

Nilai Tarif

Sumber: Dardela Yasa Guna (2009)

Gambar 2. Strategi penentuan tarif berdasarkan ATP dan WTP

Tabel 1. Tarif yang diusulkan pengelola

\begin{tabular}{ccc}
\hline \multirow{2}{*}{ Koridor } & \multicolumn{2}{c}{ Tarif (Rp.) } \\
\cline { 2 - 3 } & $\begin{array}{c}\text { Mahasiswa/ } \\
\text { pelajar }\end{array}$ & Umum \\
\hline I & 2.000 & 5.000 \\
III & 2.000 & 4.000 \\
IV & 2.000 & 8.000 \\
\hline Sumber: Dinas Perhubungan Provinsi Aceh (2016)
\end{tabular}




\section{Hasil dan Pembahasan}

Pada bagian ini disajikan karakteristik responden, nilai ATP dan WTP, serta tarif yang telah diusulkan pengelola.

\section{Karakteristik responden}

Pada koridor I, 22\% responden adalah laki-laki dan $78 \%$ responden adalah wanita. Pada koridor III, $59,1 \%$ responden adalah laki-laki dan 40,9\% responden adalah wanita. Sedangkan pada koridor IV, 50,9\% responden adalah laki-laki dan 49,1\% responden adalah wanita.

Tabel 2. Karakteristik responden berdasarkan jenis pekerjaan

\begin{tabular}{lrrr}
\hline \multicolumn{1}{c}{$\begin{array}{c}\text { Jenis } \\
\text { pekerjaan }\end{array}$} & $\begin{array}{c}\text { Koridor } \\
\text { I }\end{array}$ & $\begin{array}{c}\text { Koridor } \\
\text { III }\end{array}$ & $\begin{array}{c}\text { Koridor } \\
\text { IV }\end{array}$ \\
\hline Mahasiswa/pelajar & $81,0 \%$ & $25,5 \%$ & $25,4 \%$ \\
PNS/Polisi/TNI & $4,0 \%$ & $17,3 \%$ & $20,0 \%$ \\
Ibu rumah tangga & $4,0 \%$ & $9,1 \%$ & $13,9 \%$ \\
Pegawai swasta & $4,0 \%$ & $41,8 \%$ & $31,7 \%$ \\
Pekerjaan lainnya & $7,0 \%$ & $6,3 \%$ & $9,0 \%$ \\
\hline Total & $100,0 \%$ & $100,0 \%$ & $100,0 \%$ \\
\hline Jumlah sampel & 200,0 & 110,0 & 110,0 \\
\hline
\end{tabular}

Jenis pekerjaan responden disajikan pada Tabel 2. Pada koridor I, $81 \%$ responden adalah mahasiswa atau pelajar, sedangkan pada koridor III, 41,8\% responden adalah pegawai swasta dan $25,5 \%$ responden adalah mahasiswa atau pelajar. Untuk koridor IV, 31,7\% responden adalah pegawai swasta dan $25,4 \%$ adalah mahasiswa atau pelajar. Persentase usia responden disajikan pada Tabel 3. Terlihat bahwa, responden di ketiga koridor didominasi oleh mereka yang berusia 20 - 29 tahun, dengan rincian koridor I 55\%, koridor III 38,2\%, dan koridor IV sebesar $31,8 \%$ responden. Pada koridor I, dominasi responden juga diikuti oleh mereka yang berusia $10-19$ tahun, dimana $81 \%$ diantaranya adalah pelajar/mahasiswa, karena koridor ini melalui beberapa sekolah dan universitas.
Ditinjau dari kepemilikan surat izin mengemudi (SIM), persentase responden yang memiliki surat izin mengemudi SIM A atau C pada koridor I adalah $64 \%$, pada koridor III $74,5 \%$, dan pada koridor IV $70,9 \%$ responden. Terlihat bahwa mayoritas responden pada ketiga koridor adalah mereka yang memiliki SIM.

Tabel 3. Karakteristik Responden berdasarkan Usia

\begin{tabular}{crrr}
\hline \multicolumn{1}{c}{ Usia } & $\begin{array}{r}\text { Koridor } \\
\text { I }\end{array}$ & $\begin{array}{c}\text { Koridor } \\
\text { III }\end{array}$ & $\begin{array}{c}\text { Koridor } \\
\text { IV }\end{array}$ \\
\hline $10-19$ thn & $40,0 \%$ & $14,4 \%$ & $16,3 \%$ \\
$20-29$ thn & $55,0 \%$ & $38,2 \%$ & $31,8 \%$ \\
$30-39$ thn & $2,0 \%$ & $15,5 \%$ & $15,5 \%$ \\
$40-49$ thn & $0,0 \%$ & $15,5 \%$ & $18,2 \%$ \\
$50-69$ thn & $3,0 \%$ & $16,4 \%$ & $18,2 \%$ \\
\hline Total & $100,0 \%$ & $100,0 \%$ & $100,0 \%$ \\
\hline Jumlah sampel & 200,0 & 110,0 & 110,0 \\
\hline
\end{tabular}

Tabel 4. Karakteristik responden berdasarkan tujuan perjalanan

\begin{tabular}{lrrr}
\hline $\begin{array}{c}\text { Jenis } \\
\text { Pekerjaan }\end{array}$ & $\begin{array}{c}\text { Koridor } \\
\text { I }\end{array}$ & $\begin{array}{c}\text { Koridor } \\
\text { III }\end{array}$ & $\begin{array}{c}\text { Koridor } \\
\text { IV }\end{array}$ \\
\hline Sekolah/Kuliah & $49,0 \%$ & $18,3 \%$ & $15,1 \%$ \\
Bekerja & $3,0 \%$ & $30,3 \%$ & $23,5 \%$ \\
Belanja & $11,0 \%$ & $27,5 \%$ & $32,5 \%$ \\
Rekreasi & $31,0 \%$ & $16,9 \%$ & $18,1 \%$ \\
Lainnya & $3,0 \%$ & $7,0 \%$ & $10,8 \%$ \\
\hline Total & $100,0 \%$ & $100,0 \%$ & $100,0 \%$ \\
\hline Jumlah sampel & 200,0 & 110,0 & 110,0 \\
\hline
\end{tabular}

Karakteristik responden berdasarkan tujuan perjalanan dapat dilihat pada Tabel 4. Pada koridor I, tujuan perjalanan mayoritas responden adalah sekolah/kuliah (49\%) sedangkan sebanyak $31 \%$ tujuan perjalanan adalah rekreasi atau hiburan. Pada koridor III, responden dengan tujuan perjalanan bekerja merupakan yang dominan $(30,3 \%)$. Pada koridor IV, responden dengan tujuan perjalanan belanja adalah yang tertinggi $(32,5 \%)$ di koridor ini, yang diikuti dengan tujuan bekerja $(23,5 \%)$.

Tabel 5. Perhitungan nilai ATP responden untuk setiap jenis pekerjaan pada koridor I

\begin{tabular}{|c|c|c|c|c|c|}
\hline Jenis pekerjaan & $\begin{array}{c}\text { Rata-rata } \\
\text { pendapatan/ } \\
\text { bulan }\end{array}$ & $\begin{array}{c}\text { Persentase biaya } \\
\text { untuk } \\
\text { transportasi/bln }\end{array}$ & $\begin{array}{c}\text { Persentase } \\
\text { biaya untuk bus } \\
\text { trans } \\
\text { Koetaradja/bln }\end{array}$ & $\begin{array}{c}\text { Frekuensi } \\
\text { menggunakan } \\
\text { bus trans } \\
\text { Koetaradja/bln }\end{array}$ & ATP (Rp/pnp) \\
\hline [1] & {$[2]$} & [3] & [4] & [5] & $\begin{array}{c}{[6]=} \\
([2] \times[[3] \times[4]) /[5])\end{array}$ \\
\hline PNS/TNI/Polri & 4.071 .429 & 9,65 & 28,71 & 12,57 & 8.971 \\
\hline $\begin{array}{l}\text { Pegawai } \\
\text { swasta }\end{array}$ & 1.950 .000 & 17,69 & 19,97 & 13,20 & 5.219 \\
\hline $\begin{array}{l}\text { Ibu rumah } \\
\text { tangga (IRT) }\end{array}$ & 1.656 .250 & 18,30 & 14,07 & 11,00 & 3.876 \\
\hline Mhs/pelajar & 1.001 .553 & 24,73 & 24,30 & 11,88 & 5.067 \\
\hline Lain-lainnya & 3.125 .000 & 17,94 & 16,92 & 11,43 & 8.300 \\
\hline
\end{tabular}


Tabel 6. Perhitungan nilai ATP responden untuk setiap jenis pekerjaan pada koridor III

\begin{tabular}{|c|c|c|c|c|c|}
\hline $\begin{array}{c}\text { Jenis } \\
\text { pekerjaan }\end{array}$ & $\begin{array}{c}\text { Rata-rata } \\
\text { pendapatan/ } \\
\text { bulan (rp.) }\end{array}$ & $\begin{array}{c}\text { Persentase biaya } \\
\text { untuk } \\
\text { transportasi/bln }\end{array}$ & $\begin{array}{c}\text { Persentase biaya } \\
\text { untuk bus trans } \\
\text { Koetaradja/bln }\end{array}$ & $\begin{array}{c}\text { Frekuensi } \\
\text { menggunakan } \\
\text { bus trans } \\
\text { Koetaradja/bln }\end{array}$ & $\operatorname{ATP}(\mathbf{R p} / p n p)$ \\
\hline [1] & [2] & [3] & [4] & {$[5]$} & $\begin{array}{c}{[6]=} \\
([2] \times[[3] \times[4]) /[5])\end{array}$ \\
\hline PNS/TNI/Polri & 6.078 .947 & 22,11 & 33,95 & 2,68 & 5.665 \\
\hline $\begin{array}{l}\text { Pegawai } \\
\text { Swasta }\end{array}$ & 4.206 .522 & 21,48 & 56,96 & 2,74 & 6.262 \\
\hline $\begin{array}{l}\text { Ibu rumah } \\
\text { tangga (IRT) }\end{array}$ & 3.850 .000 & 26,90 & 44,75 & 2,90 & 5.327 \\
\hline Mhs/pelajar & 3.875 .000 & 18,67 & 64,58 & 3,00 & 5.192 \\
\hline Lain-lainnya & 3.857 .143 & 19,43 & 46,43 & 2,71 & 4.273 \\
\hline
\end{tabular}

Tabel 7. Perhitungan nilai ATP responden untuk setiap jenis pekerjaan pada koridor IV

\begin{tabular}{|c|c|c|c|c|c|}
\hline Jenis pekerjaan & $\begin{array}{c}\text { Rata-rata } \\
\text { pendapatan/ } \\
\text { bulan (rp.) }\end{array}$ & $\begin{array}{c}\text { Persentase biaya } \\
\text { untuk } \\
\text { transportasi/bln }\end{array}$ & $\begin{array}{c}\text { Persentase biaya } \\
\text { untuk bus trans } \\
\text { Koetaradja/bln }\end{array}$ & $\begin{array}{c}\text { Frekuensi } \\
\text { menggunakan } \\
\text { bus trans } \\
\text { Koetaradja/bln }\end{array}$ & ATP (Rp/pnp) \\
\hline [1] & [2] & [3] & [4] & {$[5]$} & $\begin{array}{c}{[6]=} \\
([2] \times[[3] \times[4]) /[5])\end{array}$ \\
\hline$\overline{\mathrm{PNS} / \mathrm{TNI} / \text { Polri }}$ & 5.795 .455 & 23,37 & 37,95 & 1,68 & 10.189 \\
\hline Pegawai swasta & 4.071 .429 & 28,63 & 52,57 & 1,86 & 10.998 \\
\hline $\begin{array}{l}\text { Ibu rumah } \\
\text { tangga (IRT) }\end{array}$ & 4.000 .000 & 19,67 & 73,33 & 2,67 & 7.211 \\
\hline Mhs/pelajar & 4.142 .857 & 19,58 & 95,83 & 3,61 & 7.185 \\
\hline Lain-lainnya & 5.250 .000 & 17,17 & 42,50 & 1,90 & 6.720 \\
\hline
\end{tabular}

Perhitungan nilai ATP responden pada setiap koridor tinjauan

Tabel 5 sampai 7 menunjukkan nilai ATP responden berdasarkan jenis pekerjaan pada Koridor I, III, dan IV. Nilai ATP diperoleh dari Persamaan (1) dan (2) dimana data-data tersebut diperoleh berdasarkan informasi yang diberikan responden pada pertanyaan-pertanyaan yang diajukan di kuesioner. Nilai ATP (kolom [6]) diperoleh dari perkalian antara rata-rata pendapatan/bulan (kolom [2]), persentase biaya untuk transportasi/bulan (kolom [3]). Nilai yang diperoleh kemudian dibagi dengan frekuensi responden menggunakan bus Trans Koetaradja/bulan (kolom [5]). Kolom [3] diperolehdari pembagian antara Jumlah biaya pengeluaran transportasi dengan jumlah pendapatan per bulan.

\section{Pekerjaan PNS/TNI/Polri:}

$=\frac{(R p 2.000,00 \times 1)+(R p 3.000,00 \times 0)+(R p 4.000,00 \times 1)+(R p 5.000,00 \times 0)+(R p 6.000,00 \times 1)}{3}=\operatorname{Rp} 4.000,00$

Pekerjaan pegawai swasta:

$=\frac{(R p 2.000,00 \times 1)+(R p 3.000,00 \times 2)+(R p 4.000,00 \times 2)+(R p 5.000,00 \times 1)+(R p 6.000,00 \times 0)}{6}=\operatorname{Rp} 3.500,00$

Pekerjaan ibu rumah tangga (IRT):

$=\frac{(R p 2.000,00 \times 1)+(R p 3.000,00 \times 1)+(R p 4.000,00 \times 0)+(R p 5.000,00 \times 1)+(R p 6.000,00 \times 1)}{4}=\operatorname{Rp} 4.000,00$ 
Tabel 8. Perhitungan nilai WTP responden untuk setiap jenis pekerjaan pada koridor I

\begin{tabular}{|c|c|c|c|c|c|c|c|}
\hline \multirow{2}{*}{ Jenis pekerjaan } & \multicolumn{5}{|c|}{ Jumlah responden terhadap tiap opsi tarif yang diberikan } & \multirow{2}{*}{ Total } & \multirow{2}{*}{$\begin{array}{c}\text { WTP } \\
\text { (Rp/pnp) }\end{array}$} \\
\hline & Rp2.000,00 & Rp3.000,00 & Rp4.000,00 & Rp5.000,00 & Rp6.000,00 & & \\
\hline [1] & [2] & [3] & [4] & [5] & [6] & [7] & [8] \\
\hline PNS/TNI/Polri & 1 & 0 & 1 & 0 & 1 & 3 & 4.000 \\
\hline Pegawai swasta & 1 & 2 & 2 & 1 & 0 & 6 & 3.500 \\
\hline $\begin{array}{l}\text { Ibu rumah tangga } \\
\text { (IRT) }\end{array}$ & 1 & 1 & 0 & 1 & 1 & 4 & 4.000 \\
\hline Mhs/pelajar & 5 & 2 & 5 & 1 & 1 & 14 & 3.357 \\
\hline Lain-lain & 2 & 0 & 0 & 1 & 1 & 4 & 3.750 \\
\hline
\end{tabular}

Tabel 9. Perhitungan nilai WTP responden untuk setiap jenis pekerjaan pada koridor III

\begin{tabular}{|c|c|c|c|c|c|c|c|}
\hline \multirow{2}{*}{ Jenis pekerjaan } & \multicolumn{5}{|c|}{ Jumlah responden terhadap tiap opsi tarif yang diberikan } & \multirow{2}{*}{ Total } & \multirow{2}{*}{$\begin{array}{c}\text { WTP } \\
\text { (Rp/pnp) }\end{array}$} \\
\hline & Rp2.000,00 & Rp3.000,00 & Rp4.000,00 & Rp5.000,00 & Rp6.000,00 & & \\
\hline [1] & [2] & [3] & [4] & [5] & [6] & [7] & [8] \\
\hline PNS/TNI/Polri & 8 & 6 & 2 & 3 & 0 & 19 & 3.000 \\
\hline Pegawai swasta & 13 & 10 & 11 & 10 & 2 & 46 & 3.522 \\
\hline $\begin{array}{l}\text { Ibu rumah tangga } \\
\text { (IRT) }\end{array}$ & 6 & 0 & 3 & 1 & 0 & 10 & 2.900 \\
\hline Mhs/pelajar & 14 & 9 & 3 & 1 & 1 & 28 & 2.786 \\
\hline Lain-lain & 4 & 2 & 1 & 0 & 0 & 7 & 2.571 \\
\hline
\end{tabular}

Tabel 10. Perhitungan nilai WTP responden untuk setiap jenis pekerjaan pada koridor IV

\begin{tabular}{|c|c|c|c|c|c|c|c|}
\hline \multirow{2}{*}{ Jenis Pekerjaan- } & \multicolumn{5}{|c|}{ Jumlah Responden terhadap tiap si tarif yang diberopikan } & \multirow{2}{*}{ Total } & \multirow{2}{*}{$\begin{array}{c}\text { WTP } \\
\text { (Rp/pnp) }\end{array}$} \\
\hline & Rp6.000,00 & Rp7.000,00 & Rp8.000,00 & Rp9.000,00 & Rp10.000,00 & & \\
\hline [1] & [2] & [3] & [4] & [5] & {$[6]$} & [7] & [8] \\
\hline PNS/TNI/Polri & 15 & 3 & 2 & 1 & 1 & 22 & 6.636 \\
\hline Pegawai swasta & 29 & 3 & 2 & 1 & 0 & 35 & 6.286 \\
\hline $\begin{array}{l}\text { Ibu rumah } \\
\text { tangga (IRT) }\end{array}$ & 14 & 0 & 1 & 0 & 0 & 15 & 6.133 \\
\hline Mhs/pelajar & 25 & 0 & 1 & 1 & 1 & 28 & 6.321 \\
\hline Lain-lain & 10 & 0 & 0 & 0 & 0 & 10 & 6.000 \\
\hline
\end{tabular}

Hubungan nilai ATP, WTP dari responden dan tarif yang diusulkan oleh pengelola pada koridor I, III, dan IV

Selanjutnya nilai ATP dan WTP berdasarkan pilihan responden serta tarif yang diusulkan oleh pengelola untuk setiap koridor disajikan pada Tabel 11. Hampir seluruh kategori jenis pekerjaan memiliki nilai WTP yang lebih rendah daripada ATP. Hal ini menunjukkan bahwa masyarakat mampu untuk membayar tarif yang lebih besar daripada WTP, namun hanya bersedia membayar sebesar WTP.

Untuk kategori mahasiswa/pelajar, tarif yang diusulkan oleh pengelola sama untuk ketiga koridor (Rp2.000,00), dan masih lebih rendah daripada ATP dan WTP. Dengan demikian, pengelola sebenarnya bisa meningkatkan tarif sampai ke nilai WTP tanpa perlu melakukan peningkatan pelayanan.

Sebagai contoh, tarif untuk pelajar/mahasiswa pada koridor I dideskripsikan pada Gambar 3. Tarif yang disarankan oleh pengelola pada koridor I yaitu Rp2.000,00 lebih rendah daripada WTP yaitu Rp3.357,00. Sehingga, pengelola sebenarnya masih bisa meningkatkan tarif untuk mahasiswa atau pelajar pada koridor I sampai ke nilai WTP. Contoh lainnya untuk melihat hubungan antara ATP, WTP, dan tariff yang diusulkan pengelola untuk kategori PNS/TNI/Polri di Koridor IV dapat dilihat pada Gambar 4. Tarif yang diusulkan pengelola adalah sebesar Rp8.000,00, berada di antara nilai ATP (Rp10.189,00) dan nilai WTP (Rp6.636,00). Dalam hal ini maka pengelola dapat menetapkan tarif berdasarkan usulan yang diberikan dengan catatan harus dilakukan peningkatan pelayanan pada bus Trans Koetaradja. Alternatif lainnya adalah, tarif bus dapat diberlakukan sesuai dengan nilai WTP responden dengan syarat pemerintah harus menyediakan subsidi dari selisih nilainya.

Untuk kategori masyarakat umum (PNS/TNI/Polri, pegawai swasta, ibu rumah tangga, dan masyarakat lainnya), nilai ATP-WTP terhadap tarif yang disarankan oleh pengelola untuk ketiga koridor, sangat bervariasi. 
Tabel 11. Nilai ATP, WTP, dan tarif untuk koridor I, III, dan IV

\begin{tabular}{|c|c|c|c|c|}
\hline \multirow{2}{*}{ 을 } & \multirow{2}{*}{ Kategori } & \multicolumn{3}{|c|}{$\begin{array}{c}\text { Nilai ATP, WTP, dan } \\
\text { tarif (Rp.) }\end{array}$} \\
\hline & & ATP & WTP & $\begin{array}{c}\text { Diusulkan } \\
\text { pengelola }\end{array}$ \\
\hline \multirow{5}{*}{ I } & PNS/TNI/Polri & 8.971 & 4.000 & 5.000 \\
\hline & Pegawai swasta & 5.219 & 3.500 & 5.000 \\
\hline & $\begin{array}{l}\text { Ibu rumah tangga } \\
\text { (IRT) }\end{array}$ & 3.876 & 4.000 & 5.000 \\
\hline & Mhs/pelajar & 5.067 & 3.357 & 2.000 \\
\hline & Lain-lain & 8.300 & 3.750 & 5.000 \\
\hline \multirow{5}{*}{ III } & PNS/TNI/Polri & 5.665 & 3.000 & 4.000 \\
\hline & Pegawai swasta & 6.262 & 3.522 & 4.000 \\
\hline & $\begin{array}{l}\text { Ibu rumah tangga } \\
\text { (IRT) }\end{array}$ & 5.327 & 2.900 & 4.000 \\
\hline & Mhs/pelajar & 5.192 & 2.786 & 2.000 \\
\hline & Lain-lain & 4.273 & 2.571 & 4.000 \\
\hline \multirow{5}{*}{ IV } & PNS/TNI/Polri & 10.189 & 6.636 & 8.000 \\
\hline & Pegawai swasta & 10.998 & 6.286 & 8.000 \\
\hline & $\begin{array}{l}\text { Ibu rumah tangga } \\
\text { (IRT) }\end{array}$ & 7.211 & 6.133 & 8.000 \\
\hline & Mhs/pelajar & 7.185 & 6.321 & 2.000 \\
\hline & Lain-lain & 6.720 & 6.000 & 8.000 \\
\hline
\end{tabular}

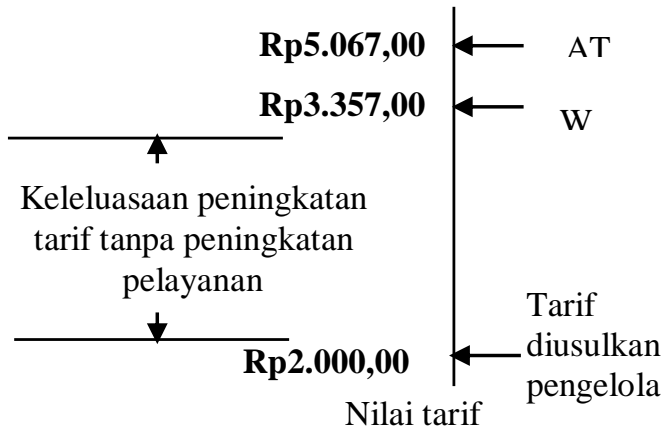

Gambar 3. Hubungan ATP, WTP, dan tarif yang diusulkan pengelola untuk segmen mahasiswa/ pelajar di koridor

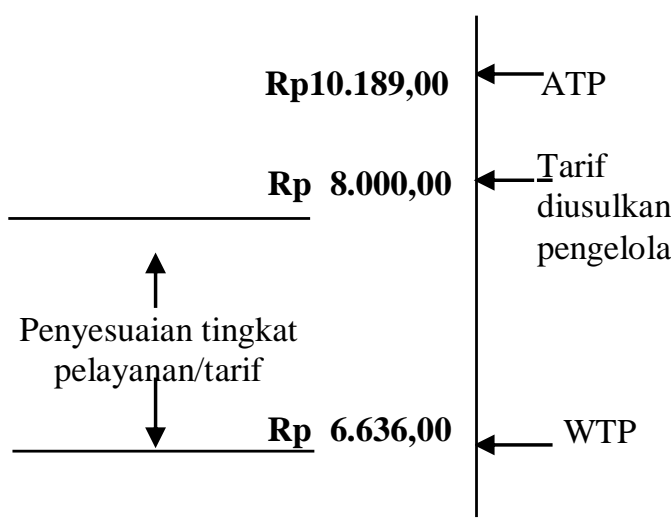

Nilai tarif

Gambar 4. Hubungan ATP, WTP, dan Tarif yang diusulkan Pengelola untuk kategori PNS/TNI/Polri di koridor IV
Untuk lebih jelasnya akan dijabarkan sebagai berikut.

Pada koridor I, hampir di semua kategori masyarakat umum menunjukkan, tarif yang diusulkan pengelola berada diantara nilai ATPWTP. Hanya kategori IRT yang nilai ATP-WTP nya berada di bawah tarif. Dengan demikian, pada koridor I nilai WTP rata-rata sebesar Rp3.812,50 (dibulatkan Rp3.800,00) dapat dijadikan tarif usulan untuk koridor I, atau dilakukan penyesuaian tingkat pelayanan, sehingga tarif usulan pengelola (Rp5.000,00) dapat diterapkan.

Pada koridor III, semua kategori masyarakat umum menunjukkan nilai tarif yang berada di antara nilai ATP-WTP. Oleh karena itu, nilai WTP rata-rata dapat dijadikan sebagai tarif usulan pada koridor III, yaitu sebesar Rp2.998,25 (dibulatkan Rp3.000,00). Jika tarif usulan pengelola (Rp4.000,00) ingin diterapkan, maka perlu adanya peningkatan pelayanan.

Pada koridor IV, nilai WTP dari semua kategori masyarakat umum berada di bawah tarif usulan pengelola (Rp8.000,00), walaupun demikian terdapat perbedaan pada nilai ATPnya. Untuk kategori PNS/TNI/Polri dan pegawai swasta, nilai ATP berada di atas tarif usulan pengelola, sedangkan sebaliknya untuk kategori IRT dan masyarakat lainnya. Oleh karena itu, jika nilai WTP rata-rata ingin dijadikan tarif usulan, nilainya sebesar Rp6.263,75 (dibulatkan Rp6.300,00). Sedangkan jika tarif usulan pengelola ingin diterapkan, maka peningkatan pelayanan perlu lebih ditingkatkan.

Sebagai contoh, tarif untuk kategori PNS/TNI/Polri pada koridor IV dideskripsikan pada Gambar 4. Tarif yang disarankan oleh pengelola pada koridor IV yaitu Rp8.000,00 lebih besar daripada WTP yang besarnya Rp6.636,00. Namun, tarif yang diusulkan oleh pengelola lebih rendah daripada ATP yang besarnya Rp10.189,00. Sehingga, pengelola bisa meningkatkan tarif untuk kategori PNS/TNI/Polri hingga Rp8.000,00 dengan syarat dilakukannya perbaikan tingkat pelayanan, atau mengikuti nilai WTP dari PNS/TNI/Polri, yaitu sebesar Rp6.636,00 (dibulatkan menjadi Rp6.700,00).

\section{Kesimpulan}

Berdasarkan hasil yang diperoleh, kemampuan dan kemauan masyarakat dalam membayar tarif bus Trans Koetaradja berbeda-beda, tergantung dari kategori masyarakat. Secara umum, tarif usulan pengelola untuk kategori mahasiswa/pelajar adalah sama untuk ketiga koridor, yaitu sebesar 
Rp2.000,00. Usulan tarif ternyata jauh dibawah nilai ATP-WTP mahasiswa/pelajar pada ketiga koridor. Dalam hal ini pengelola masih memiliki keleluasaan melakukan peningkatan tarif tanpa perlu melakukan peningkatan pelayanan. Namun demikian, penelitian ini merekomendasikan tarif untuk mahasiswa/pelajar adalah tetap, yaitu sebesar Rp2.000,00 untuk masing-masing koridor. Untuk kategori masyarakat umum (PNS/TNI/Polri, pegawai swasta, ibu rumah tangga, dan masyarakat lainnya), nilai WTP berada di bawah tarif usulan pengelola untuk ketiga koridor. Oleh karena itu penelitian ini merekomendasikan penetapan tarif untuk masing-masing koridor adalah berdasarkan nilai rata-rata WTP, yaitu Rp3.800,00 (untuk koridor I), Rp3.000,00 (untuk koridor III), dan Rp6.300,00 (untuk koridor IV). Sedangkan jika ingin diterapkan tarif usulan pengelola, maka perlu ada peningkatan pelayanan pada ketiga koridor.

\section{Daftar Pustaka}

Anggraini, R., Sugiarto, S., \& Pramanda, H. (2017, Agustus). Factors Affecting Trip Generation of Motorcyclist for the Purpose of Non-Mandatory Activities. Paper presented at the $3^{\text {rd }}$ International Conference on Construction and Building Engineering (ICONBUILD), Department of Civil Engineering, Sriwijaya University, Palembang, Indonesia.

Aviasti, R., Djamaluddin, A.N. (2014, September). Model Penentuan Tarif Angkutan Kota berdasarkan Keterjangkauan Daya Beli Masyarakat Pengguna di Kota Bandung (Studi Kasus: Trayek Sadang Serang-Caringin dan Trayek Margahayu Raya - Ledeng). Yang dipresentasikan pada Seminar Nasional Penelitian dan Pengabdian pada Masyarakat (SNaPP), Universitas Islam Bandung, Bandung, Indonesia.

Dardela Yasa Guna, (2009). Ability to Pay/Willingness to Pay. Retrieved Januari, 2019, from http://www.dardela.com

Dinas Perhubungan Provinsi Aceh, (2016). Data realisasi angkutan bus rapid transit tahun 20162017 Provinsi Aceh, Banda Aceh.

Joewono, T. B. (2009). Exploring the Willingness to Pay and Ability to Pay for Paratransit in Bandung, Indonesia. Journal of Public Transportation, 12(2), 85-103.

Julien, \& Mahalli, K. (2014). Analisis Ability to Pay dan Willingness to Pay Pengguna Jasa Kereta Api Bandara Kualanamu (Airport Railink Service). Jurnal Ekonomi dan Keuangan, 2(3), 167-179.
McCollon, B. E., \& Pratt, R. H. (2004). TCRP (transit cooperative research program) report 95, Transportation Research Board, DC: Washington.

Nuworsoo, C., Deakin, E., \& Golub, A. (2008). Equity Impacts of Transit Fare Proposals: A Case Study of AC Transit. Journal of the Transportation Research Forum, 47(3), 23-43.

Permata, M. R. (2012). Analisa Ability to Pay dan Willingness to Pay Pengguna Jasa Kereta Api Bandara Soekarno-Hatta Manggarai, Jakarta. Master Tesis, Indonesia: Universitas Indonesia.

Rahmi, N. (2016). Analisis Pemilihan Moda akibat Kebijakan Pengoperasian Bus Trans Koetaradja di Kota Banda Aceh. Skripsi, Indonesia: Universitas Syiah Kuala.

Rumiati, Fahmi, K., \& Edison, B. (2013). Analisis Kemampuan dan Kemauan Membayar Tarif Angkutan Umum Mini Bus (SUPERBEN) di Kabupaten Rokan Hulu. Jurnal Online Teknik Sipil Universitas Pasir Pengaraian, 1(1), 1-7.

Safitri, R. (2016). Evaluasi Tarif Angkutan Umum berdasarkan Ability to Pay (ATP) dan Willingness to Pay di Kota Pangkalpinang. Jurnal Fropil, 4(2), $156-164$

Setijowarno, D., \& Putranto, P. P. (2015, Agustus). Ability to Pay dan Willingness to Pay Angkutan Umum di Kabupaten Belitung. Di presentasikan pada Simposium Forum Studi Transportasi antar Perguruan Tinggi (FSTPT) ke-18, Jurusan Teknik Sipil, Universitas Lampung, Bandar Lampung, Indonesia.

Susantono, B., Santosa, W., \& Budiarto, A. (2011). Kepemilikan Kendaraan dan Pola Perjalanan di Wilayah Jabodetabek. Jurnal Transportasi, 11(3), 153-162.

Tamin, O. Z., Rahman, H., Kusumawati, A., Munandar, A. S., \& Setiadji, B. H. (1999). Evaluasi Angkutan Umum dan Ability to Pay (ATP) dan Willingness to Pay (WTP) di DKI Jakarta. Jurnal Transportasi, 1(2), 121-139.

Wulansari, D.N., Tamin, O.Z., Wibowo, S.S., Weningtyas, W. (2015, Agustus). Analisis Ability to Pay (ATP) dan Willingness to Pay (WTP) Pengguna Kereta Api Bandara (Studi Kasus: Bandar Udara Internasional Soekarno-Hatta). Di presentasikan pada Simposium Forum Studi Transportasi antar Perguruan Tinggi (FSTPT) ke-18Jurusan Teknik Sipil, Universitas Lampung, Bandar Lampung, Indonesia. 